\title{
Production Innovation 'Jelly Siwalan Dry' For Extending The Endurance Of Fruit Consumption
}

\author{
Author \\ Anggia Kalista (Orcid ID. 0000-0003-3470-5757), Krishna Tri Sanjaya (Orcid ID. 0000-0003-2765-2693), \\ Agus Wardhono (Orcid ID. 0000-0003-0372-2597) \\ Correspondence \\ Universitas PGRI Ronggolawe Tuban \\ anggiakalista@gmail.com
}

\begin{abstract}
Siwalan is the fruit of a palm tree growing up in the City of Tuban. The fruit is less favoured because of quick foul and challenging to eat it. The author tried to expand the innovation and introduced it to society to consume Siwalan practically, effectively. One of them is to process it into candy 'Dried Jelly Siwalan'. The purpose of this innovation is to extend the endurance of consumption of Siwalan to be able to survive more than one month at room temperature and two months in the fridge without preservatives. Dried Candy Jelly Siwalan is made from natural ingredients and exciting colours. This is intended to increase the interest of consumption of society, particularly children and tourists who affect the creation of business opportunities to improve the community's economy.
\end{abstract}

Keywords: Dried Jelly Siwalan; Innovation; Siwalan

Received: 10 May 2021. Accepted: 22 June 2021

\section{Introduction}

Siwalan is one of the plantation crop commodities in Tuban City besides coconut, cashew, cottonwood, cananga and others. (Disparbudpora. Tuban, 2018). Siwalan trees grow a lot in Tuban Regency, especially in dryland areas. Plants that grow in the lowlands have many benefits. The community uses sweet water for drinking and processing the sap by heating it to produce brown sugar (Tambunan, 2010). The young Siwalan fruit is processed into snack food. (Apriyanti, 2018). Besides being delicious for direct consumption, it can also be used as a mixture for drinks (Arsyad, 2015) (Arsyad, 2015)like fruit ice. Tree trunks and leaves can be used for various household purposes (Bapeda, 2013). In 2018, palm oil production was 7,090.77 tons (BPS Kab. Tuban, 2019).

Siwalan is a delicious, fresh, and healthy fruit, so it's no wonder most people are highly interested in this fruit. Siwalan fruit has a delightful taste and has a high nutritional content and contains antioxidant compounds so that it is helpful as a source of natural antioxidants for the body (Idayanti, Suparmo, \& Darmadji, 2014). In addition, Siwalan fruit also contains vitamin E, which is more significant when compared to the content of vitamin $\mathrm{E}$ in sugar palm fruit (Widada, 2013), so consuming Siwalan fruit will undoubtedly be very good for the body. Most people consume Siwalan fruit directly, or in other words, they rarely consume Siwalan fruit by doing specific processing. This is because the fruit itself tastes delicious even without processing (Krisnawati, I., 2019).

However, Siwalan fruit is less popular as a souvenir because it is easily rotten or slimy, and it isn't easy to consume. Tuban city, a tourist city (Kalista, 2019), the sale of palm fruit is still in raw form when used as souvenirs. People are still reluctant to buy it 
because the fruit is not durable and difficult to consume (impractical), especially the children who are not interested in this healthy fruit. Therefore, the lack of public knowledge about the variety of Siwalan processing also contributes to consuming Siwalan fruit, which has a lot of nutritional content and contains many health benefits (Aisiyah, Thohari \& Purwadi, 2015).

This dried Siwalan jelly product is one solution to problems that arise in the community or partners related to the problem of less durable palm fruit management. With this innovation, this food security can last approximately one month at room temperature and two months in the refrigerator without preservatives. This dried Siwalan jelly product will become a local product typical of Tuban, which is visited by many tourists from outside the region every day.

So that this dried Siwalan jelly is expected to be used as one of the typical souvenirs of the city of Tuban, to be able to increase public consumption interest in palm fruit, also in the hope that it can increase business opportunities that have an impact on improving the community's economy, dry Siwalan jelly is made with attractive colours, so it is hoped that it can attract children, especially kindergarten and elementary school children. The content of vitamins and pure sugar in Siwalan fruit is safe for children and the general public.

\section{Method}

To obtain accurate problem data as reflective material, direct observations and interviews were carried out with palm traders. Comments are made to determine real solutions in solving problems faced by partners.

When making dried Siwalan jelly, the method used is group discussion and direct practice (learning by doing). The use of this method is expected to improve the understanding and skills of partners related to the technique of making Jelly Siwalan.

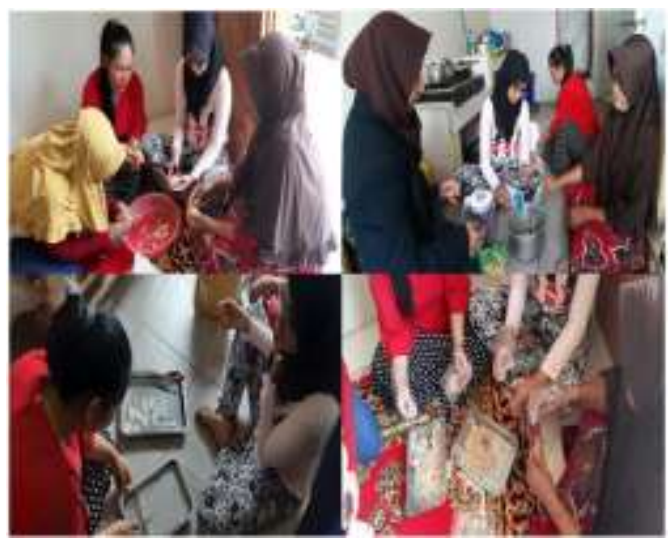

Figure 1. Community Involvement in the Process of Making Dried Siwalan Jelly

The steps for making Jelly Siwalan can be seen in Table 1.

Table 1. Making Jelly Siwalan

\begin{tabular}{|c|c|c|}
\hline No. & Stages & Information \\
\hline 1 & Preparation & $\begin{array}{l}\text { Prepare the tools and } \\
\text { materials needed, namely } \\
\text { a pot, measuring cup, } \\
\text { blender, stirrer, mold, } \\
\text { palm fruit, jelly powder, } \\
\text { sugar and water. }\end{array}$ \\
\hline 2 & Stripping & $\begin{array}{l}\text { The Siwalan is peeled } \\
\text { first until it leaves the } \\
\text { white part of the meat. } \\
\text { The Siwalan flesh is then } \\
\text { crushed in a blender until } \\
\text { smooth. }\end{array}$ \\
\hline 3 & Cooked & $\begin{array}{l}\text { The crushed Siwalan is } \\
\text { cooked in a pan. Add } \\
\text { water, sugar to taste and } \\
\text { jelly powder. Then stir } \\
\text { until boiling. }\end{array}$ \\
\hline 4 & Cooling & $\begin{array}{l}\text { Cooling is done by } \\
\text { letting the dough in the } \\
\text { mold cool down until } \\
\text { there is no hot steam and } \\
\text { it is chewy so that during } \\
\text { the cutting process, it is } \\
\text { not destroyed. }\end{array}$ \\
\hline 6 & $\begin{array}{l}\text { Cutting / } \\
\text { Unmounting }\end{array}$ & $\begin{array}{l}\text { After the jelly has } \\
\text { cooled, cut (if the jelly is }\end{array}$ \\
\hline
\end{tabular}




\begin{tabular}{|l|l|l|}
\hline & & $\begin{array}{l}\text { placed on a large baking } \\
\text { sheet) or detach from the } \\
\text { mould (if using a mold). }\end{array}$ \\
\hline 7 & Drying & $\begin{array}{l}\text { The Siwalan jelly is then } \\
\text { dried in the sun for about } \\
\text { three days until the } \\
\text { outside of the Siwalan } \\
\text { jelly is dry. This } \\
\text { functions to remove the } \\
\text { moisture content in the } \\
\text { jelly so that the jelly can } \\
\text { last a long time even } \\
\text { without using } \\
\text { preservatives. }\end{array}$ \\
\hline 8 & Packaging & $\begin{array}{l}\text { Dry jelly candy, packed } \\
\text { in transparent plastic and } \\
\text { tightly closed so that no } \\
\text { air enters and Jelly } \\
\text { Siwalan is ready to be } \\
\text { marketed. }\end{array}$ \\
\hline
\end{tabular}

\section{Results and Discussion}

After the Siwalan Jelly-making process, for about three days, monitoring is carried out whether the jelly previously made is completely dry or not and then the packaging process is carried out. To determine the success of this activity, it is necessary to evaluate partners. The evaluation of activities includes understanding and ability to make Jelly Siwalan. In addition, periodic monitoring will be carried out so that this program will continue.

Because this product is a jelly made from Siwalan, so it has a distinctive taste of Siwalan fruit, so it is suitable to be used as a typical souvenir of the city of Tuban. Dry Siwalan jelly products are packaged in

simple packaging and have attractive colour variations. They are sold at affordable prices to be enjoyed by all people, especially children and residents from outside Tuban City. This dried Siwalan jelly is made into unique food products and by using food ingredients that are safe for consumption and do not use preservatives. With the durability of 1 month at room temperature and approximately two months in the refrigerator.

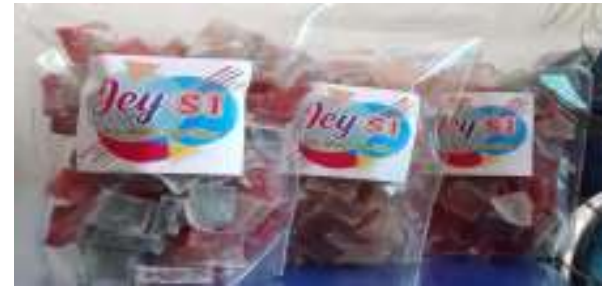

Figure 2. Packaged Dried Siwalan Jelly Products

After the Siwalan jelly doing training was carried out, most people were interested in making Siwalan jelly at home, both for marketing and consumption. This is evidenced by the results of the questionnaires that were distributed after this community service program was carried out. The questions that have been shared are as follows:

1. What do you feel after receiving this training?

2. After participating in this activity, will you make Siwalan jelly at home as an innovation in processing palm fruit?

3. If you answered "Yes" to question no. 2, are you going to make Siwalan jelly for your consumption, or will you sell it too?

4. Suppose you answered "a" or "b" in question no. What three innovations will you develop on Siwalan jelly products? (maybe more than one innovation)

5. Write down your suggestions about this Community Service activity!

Table 2. Questionnaire Results of Partners' Interest in Producing Dried Siwalan Jelly

\begin{tabular}{|c|c|c|}
\hline Category & Frequency & $\begin{array}{c}\text { Percentage } \\
(\%)\end{array}$ \\
\hline $\begin{array}{c}\text { Consume it } \\
\text { yourself }\end{array}$ & 7 & 35 \\
\hline $\begin{array}{c}\text { Own } \\
\text { Consuming } \\
\text { and Selling }\end{array}$ & 10 & 50 \\
\hline Doubtful & 1 & 5 \\
\hline Not Selling & 2 & 10 \\
\hline
\end{tabular}




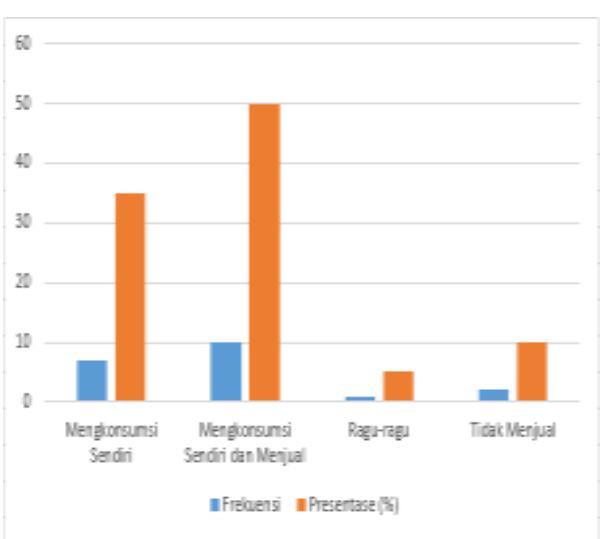

Figure 3. Questionnaire Result Diagram of Partners' Interest in Producing Dried Siwalan Jelly

Partners' interests are categorized into four categories. Namely, $35 \%$ want to consume themselves, 50\% want to drink and sell themselves, 5\% answer they are doubtful, and $10 \%$ do not sell them. Based on the results of the questionnaire, it can be concluded that the partners are very interested in re-making dried Siwalan jelly either for their consumption or for resale.

The inhibiting factor of the process of making this Siwalan jelly is the weather. This is because, in the drying process, jelly needs natural heat from the sun. So if the weather is cloudy or rainy, it will extend the time in the jelly drying process. So that it will affect the resistance of the jelly, the jelly will be stale or slimy if the jelly is wet for too long (the water content does not decrease).

\section{Conclusion}

The advantage in this innovative processing of Siwalan fruit into dried Siwalan jelly candy is that many children like the taste and texture that is similar to jelly candy on the market. And the response from some newcomers or tourists is also very fond of this Siwalan jelly candy because of its practicality and extended durability, so it is easy to carry as souvenirs.
However, the weakness in the process of making this Siwalan jelly candy is that it is very dependent on the weather. This is because, in the drying process, jelly needs natural heat from the sun. So if the weather is cloudy or rainy, it will extend the time in the jelly drying process. So that it will affect the resistance of the jelly, the jelly will be stale or slimy if the jelly is wet for too long (the water content does not decrease). So that innovation is needed so that in making this Siwalan jelly, it can stay dry without changing the taste of the Siwalan jelly candy even though the weather is cloudy or rainy.

\section{References}

Tambunan, P. (2010). Potensi dan Kebijakan Pengembangan Lontara untuk Menambah Pendapatan Penduduk. Jurnal Analisis Kebijakan Kehutanan, 7(1), 27-45.

Bapeda. (2013). Potensi dan Produk Unggulan Jawa Timur. Tuban.

Widada, H. (2013). Analisis Kandungan Vitamin E pada Buah Borassus flabellifer Linn . Menggunakan High Performance Liquid Chromatography (HPLC). Mutiara Medika, 13(3), 147154.

Idayanti, E., Suparmo, \& Darmadji, P. (2014). Potensi Senyawa Bioaktif Mesocarp Buah Lontar (Borassus flabeliffer L.) sebagai Sumber Anti Oksidan Alami. Jurnal Agritech, 34(3), 277-284.

Aisiyah, S., Thohari, I., \& Purwadi. (2015). The Addition of Flesh Palm ( Borassus flabellifer) on Quality of Ice Cream Based on Water Holding Capacity, Viscosity, Moisture and Melting Point. Malang.

Arsyad, M. (2015). Etnobotani di Desa Bonto Kassi Kecamatan Galesong Selatan Kabupaten Takalar Makasar. UIN Alaudin Makasar

Disparbudpora. Tuban. (2018). Situs Resmi Pemerintah Kabupaten Tuban. Tuban: Pemda. 
Kalista, A. et al. (2019). Implementation of Tourism Information System at Tuban Regency. Journal Kontribusia, 2(2), 21$27 . \quad$ Retrieved from http://journal.umg.ac.id/index.php/kontri busia/article/download/1005/801

Krisnawati, I., et all. (2019). J-LAN (Jelly Siwalan Khas Tuban) Kekayan Lokal Bumi Wali. Prosiding Seminar Nasional, 4 